\title{
Agricultural seed biodiversity: a book review of janisse ray's the seed underground: a growing revolution to save food
}

\begin{abstract}
Greatly concerned with the possibility that the loss of agricultural seed diversity will affect global food supply, Ray stands as a farming radical armed with a historical record of seed development and decline and modification in the hopes of arming the reader with the knowledge and the desire to preserve seed diversity going forward into the next generation.
\end{abstract}

Volume I Issue I - 2017

\author{
Allison Joy Bailey \\ Institute for Environmental \& Spatial Analysis, University of \\ North Georgia, Georgia
}

Correspondence: Allison Joy Bailey, Institute for Environmental \& Spatial Analysis, University of North Georgia. Georgia,Tel 470-239-3।35,Email allison.bailey@ung.edu

Received: February 14, 2017 | Published: March 03, 2017

\section{Book review}

Agricultural seed diversity is crucial for our survival as a species. Throughout human history there have been many cases where agricultural crops didn't produce a harvest plenty enough to feed the national population of the country in which the crops were grown. The Irish Potato Famine was caused by blight to the preferred species of potato. The Great American Dust Bowl caused by climate conditions to which Midwestern United States farmers could not bring their grain crops to yield. This is the past; however, the present state of food crops isn't limited to feeding people within national borders. Food is imported and exported around the world. A rise in civilization has been directly correlated to a rise in seed diversity. Consequently, the continued decline in seed diversity could lead to a fall in civilization.

Through anecdotal stories of seeds and the farmers who love them, Ray poignantly discusses the reality of the loss of seed diversity among agricultural crops in the book "The Seed Underground: A Growing Revolution to Save Food". Serving as an encyclopedia of the development of agribusiness, hybridization of crops, seed saving by local farmers, heritage seeds, seed banks, genetic drift, hand pollination, and court cases involving genetically modified organism creating companies and local farmers unfortunate enough to attempt to preserve seed diversity and be located adjacent to a commercial farm using Round-Up Ready seeds, Ray provides the reader with an overview of the increase and decrease of seed diversity among agricultural crops.

The major complaint Ray makes is that we are losing the possibility to grow multiple species of food and thereby increasing our vulnerability towards food insecurity on a local and global scale. Corn is just one example crop Ray cites that can be traced from its origins to today's agricultural practices. Ray (2012) recounts "Corn, for example, was not discovered in some far valley, pendent with plump, sweet ears. No -- cornwas developed." The cobs of corn which are harvested today are not the first domesticated crop of corn. The genetic origin of corn is teosinte harvested by Mesoamerican women in the Balas Valley, Mexico, approximately 9000 years ago. From this point in time, Ray discusses corn as if each species or variety of corn was a beloved family member. Travelling the country to visit local farmers who still save seeds, Ray acquires seeds and farming stories of Maize, Stanley corn, and Keener corn. The majority of corn grown today, Ray asserts, is Golden Cross Bantam likely chosen for its resistance to wilt. In the book section on hybrids, Ray cites that in 1924 the "first hybrids were two varieties of corn" to reach the US agricultural market: Red green and Copper Cross. However, saving hybrid seeds is not possible; thus causing the development of agribusiness which sold newly hybridized seeds to farmers each planting season.

Farmers stopped saving seeds passed down through generations of farming families in favor of better performing hybrid seeds. In 1935, her book records that over 1000 varieties of corn were grown in Iowa, and by $1939,90 \%$ of Iowa corn was hybridized with Golden Cross Bantam. This marks the year that Midwestern United States corn lost its biodiversity. And then in the 1996, genetically modified seeds hit the agricultural market in an attempt to make agricultural crops pesticide resistant. In 2009, Smarts tax, the first GM corn was introduced to market and farmers embraced Smarts tax as the savior seed to feed the world's population. With the exception of a few heritage seeds stored in food banks or planted by organic farmers, corn is now almost completely a single seed type. Ray warns that this loss of biodiversity in corn, a major agricultural crop found in almost everything on the supermarket shelf, could lead to civilization's decline. Is the Global Corn Famine in our future? What will happen to the global food supply if Smarts tax corn stops producing either due to disease, climate conditions, or other unforeseen factors?

Loss of biodiversity affects our food. Ray cites nine ways that the agricultural food system in the United States is broken:
i. Our food is going extinct.
ii. Our food supply is being stolen from us.
iii. Our food supply is being bought out from under us.
iv. Bad food has been forced down our throats.
v. Our food is hazardous to our health.
vi. Our food is harming the earth.
vii. Our food annihilates pollinators.
viii. Our food is nutritiously impotent.
ix. Our food threatens democracy. 
This explains why Ray chose the title "The Seed Underground: A Growing Revolution to Save Food". Greatly concerned with the possibility that the loss of agricultural seed diversity will affect global food supply, Ray stands as a farming radical armed with a historical record of seed development and decline and modification in the hopes of arming the reader with the knowledge and the desire to preserve seed diversity going forward into the next generation.

\section{Acknowledgements}

None.

\section{Conflict of interest}

Author declares there is no conflict of interest in publishing the article. 